\title{
Estimate of sulfur, arsenic, mercury, fluorine emissions due to spontaneous combustion of coal gangue: An important part of Chinese emission inventories
}

\author{
Shaobin Wang ${ }^{\text {a, b }}$, Kunli Luo ${ }^{\text {a, *, Xing Wang }}{ }^{c}$, Yuzhuang Sun ${ }^{\text {d }}$ \\ a Institute of Geographic Sciences and Natural Resources Research, Chinese Academy of Sciences, Beijing 100101, China \\ ${ }^{\mathrm{b}}$ University of Chinese Academy of Sciences, Beijing 100049, China \\ ${ }^{c}$ Key Laboratory of Coal Resources Exploration and Comprehensive Utilization, Ministry of Land and Resources of P. R. China, Xi'an 710021, China \\ d Key Laboratory of Hebei Province for Resource Exploration Research, Hebei University of Engineering, Handan 056038, China
}

\section{A R T I C L E I N F O}

\section{Article history:}

Received 29 July 2015

Received in revised form

19 November 2015

Accepted 19 November 2015

Available online 7 December 2015

\section{Keywords:}

China

Coal gangue spontaneous combustion

As, $\mathrm{Hg}$ and $\mathrm{F}$ emissions

Sulfur and harmful trace elements

\begin{abstract}
A B S T R A C T
A rough estimate of the annual amount of sulfur, arsenic, mercury and fluoride emission from spontaneous combustion of coal gangue in China was determined. The weighted mean concentrations of $\mathrm{S}$, As, $\mathrm{Hg}$, and $\mathrm{F}$ in coal gangue are $1.01 \%, 7.98,0.18$, and $365.54 \mathrm{mg} / \mathrm{kg}$, respectively. Amounts of $\mathrm{S}, \mathrm{As}, \mathrm{Hg}$, and F emissions from coal gangue spontaneous combustion show approximately $1.13 \mathrm{Mt}$, and 246, 45, and 63,298 tons in 2013, respectively. The atmospheric release amount of sulfur from coal gangue is more than one tenth of this from coal combustion, and the amounts of As, Hg, and F are close to or even exceed those from coal combustion. China's coal gangue production growth from 1992 to 2013 show an obvious growth since 2002. It may indicate that Chinese coal gangue has become a potential source of air pollution, which should be included in emission inventories.
\end{abstract}

() 2015 Elsevier Ltd. All rights reserved.

\section{Introduction}

Coal gangue is one of the largest industrial residues in China that is discharged during the processing and utilization of coal ( $\mathrm{Gu}$, 1997; Liu and Liu, 2010). With continuous growth of coal mining and coal cleaning, a large amount of coal gangue are produced, which contain sulfide minerals, alumino-silicates minerals, other inorganic minerals, and organic matter (Querol et al., 2008; Zhao et al., 2008; Zhou et al., 2014). The current disposal of such a large quantity of coal gangue occupies a lot of land and has caused many serious environmental problems (e.g. Querol et al., 2008; Bian et al., 2009; Zhou et al., 2014). Among them, spontaneous combustion of coal gangue stockpiles is a serious environmental concern in China, and hazardous trace elements are released into the atmosphere (Zhao et al., 2008).

Extensive studies focused on toxic trace elements released from coal combustion and its air pollution in China (e.g. Wang et al.,

\footnotetext{
* Corresponding author. Institute of Geographical Sciences \& Natural Resource Research, Chinese Academy of Sciences, A11 Datun Road, Anwai, Beijing 100101, China.

E-mail address: luokl@igsnrr.ac.cn (K. Luo).
}

2000; Zhang and Zhao, 2007; Tian et al., 2010; You and Xu, 2010; Chen et al., 2013; Liu et al., 2013). Some studies involved the trace elements abundance properties, toxicity and partitioning characterization of coal gangue, and the control of its spontaneous combustion (e.g. Querol et al., 2008; Zhao et al., 2008; Fu et al., 2012; Zhou et al., 2012, 2014). However, few quantitative estimates have been conducted on total emissions of sulfur and toxic trace elements (e.g. As, $\mathrm{Hg}$, and F) during spontaneous combustion of coal gangue in China. Consequently, their environmental impacts and proportion in total atmospheric release in China are still obscure.

Since the takeoff of China's economy, environmental issues, including air pollution, have become a matter of concern by the public. The heavy air pollution has become frequent in recent years in China, and has had serious influence on the urban and rural atmospheric environment, traffic safety, industrial, agricultural development, etc. (e.g. He et al., 2002; Tie et al., 2006; Ma et al., 2010; Leung et al., 2014). Chinese official data and other studies manifest that industrial sulfur dioxide emissions peaked in 2006, and then it exhibited a downward trend (MEPC, 1996-2011, 2012-2013; Zhang et al., 2012; Klimont et al., 2013). However, it is still unclear whether there exist some undetermined emission sources such as coal gangue. 
To attain a better understanding of the emission of sulfur, arsenic, mercury, and fluoride due to spontaneous combustion of coal gangue, we collected representative coal gangue samples from large coal mines in Shaanxi, Shanxi, and Shandong Provinces, the most important energy resources bases in China. We determined the sulfur, arsenic, mercury, and fluorine contents in these samples and calculated the average contents of the samples based on weight of coal reserves in the different coal-forming period. Furthermore, this study provides a rough quantitative estimate of the total annual amount of sulfur, arsenic, mercury, and fluoride emission from spontaneous combustion of coal gangue. Finally, we payed attention to the long-term emission trends of sulfur dioxide from coal gangue and total sulfur dioxide emission in China. The estimate and addressing of potential source of air pollution in China may enable researchers and policy-makers to be more effective.

\section{Materials and methods}

\subsection{Geographic and geological background}

Chinese coal resources are unevenly distributed with more in the north and west than in the south and the east. The main coalforming periods with the largest reserves in China were the Carboniferous, Permian, and Jurassic. Coal in the North China and Northwest China accounts for nearly $84 \%$ of total Chinese coal reserves, and lignite in Northeast China accounts for only about $4 \%$, while coal in southern China only accounts to 9\% (Chen and Zhang, 1993; Mao and Xu, 1999).

Hancheng, Chenghe, and Tongchuan coal mines are located at the Weibei coalfield in Shaanxi Province (Fig. 1). These coal mines and the Shenfu coalfield are in the Erdos Basin, which is one of the most important energy resources bases in China. The coal-bearing stratum in the Weibei Coalfield in Shaanxi Province, the Xishan Coalfield in Shanxi Province, and the Pingyin Coalfield in Shandong Province are in the Pennsylvanian Taiyuan Formation and the lower Permian Shanxi Formation. The Bindong coal mine and Linyou coal mine is located in Jurassic Huanglong Coalfield, southeastern Ordos Basin (Fig. 1), and the coal-bearing stratum in the Huanglong
Coalfield and Shenfu Coalfield are in the middle Jurassic Yan'an Formation.

\subsection{Samples}

Samples are mainly from Permo-Carboniferous coal from the Hancheng coal mine, the Tongchuan coal mine, the Chenghe coal mine, and the Shenfu coal mine in Shaanxi Province; the Xishan coal mine in Shanxi Province and Pingyin coal mine in Shandong Province. Jurassic coal from the Bindong and Linyou mines are mainly used as steam coal. It is reasonable to collect these samples and analyze their elemental contents according to their geologic ages rather than coal types (Luo et al., 2002). Methods of sampling in this paper are mainly channel sampling and strip sampling based on GB 482-1995 (Chinese standard of coal seam sampling) (Yang et al., 1998). In the Bindong, Linyou and Hancheng coal mines, samples of coal gangue in the channel were collected after a straight channel was made in the coal bed workface. Mixed samples of coal gangue in stockpiles are from the Chenghe, Shenfu, Xishan, and Pingyin coal mines. All collected samples were pulverized and passed through a 150 -mesh sieve, then every homogenized sample was dried for two days at $50{ }^{\circ} \mathrm{C}$ and stored in a desiccator.

\subsection{Determination of sulfur, arsenic, mercury, and fluorine content}

The content of sulfur was determined by High Temperature Catalytic - Coulometric Titration method (GB/T 214-2007) (AQSIQ-SAC, 2007). The content of sulfur of the standard reference materials GBW11103g, GBW11107j, and GBW11112d (coal, from Testing Center of China Coal Research Institute) was randomly analyzed with each batch of samples, respectively. The relative standard deviation was $10^{-1}$, and the detection limit was $10^{-4}$.

The content of fluorine was determined by pyrohydrolysis/ fluorine ion-selective electrode method (Yang et al., 1998). For quality control, the standard reference materials [(GBW11122 (coal), GBW08402 (coal fly ash), Chinese Standard Sample Study Center, Chinese Academy of Measurement Sciences] were randomly analyzed with each batch of coal gangue samples,
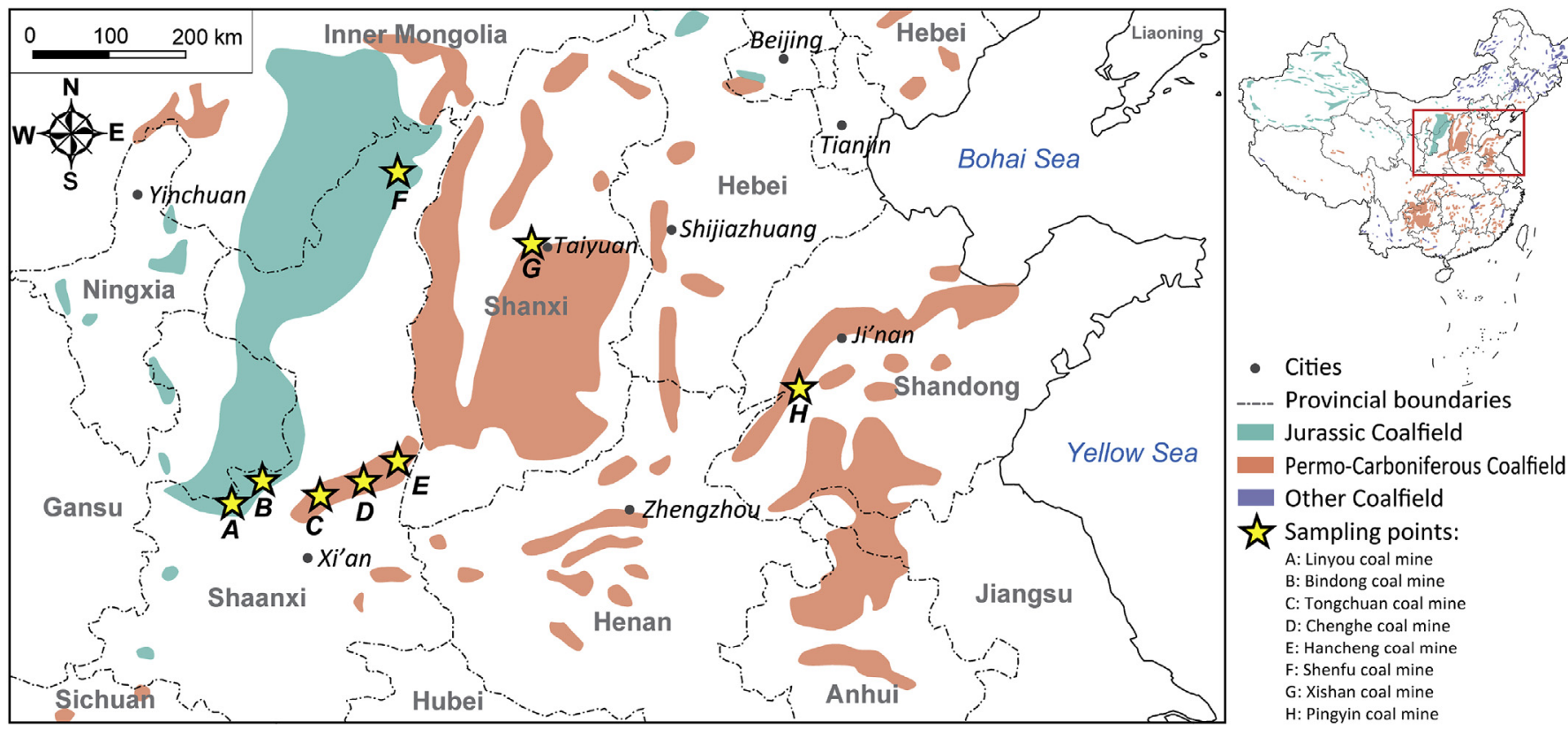

Fig. 1. Geographic setting and location of sampling coal mines. 
respectively. The relative standard deviation was less than $10^{-1}$, and the detection limit was $10^{-9}$.

Arsenic and mercury in coal gangue are determined by electric hot plate-mixed-acids-hydride generation atomic fluorescence spectrometry (HG-AFS) (Luo, 2005; Zhang et al., 2006; Ni and Luo, 2015). The following standard reference materials were randomly analyzed with each batch of coal gangue samples: GBW 07408 (GSS-8, soil, China), GBW 07107 (GSR-5, rock, China), GBW 07114 (GSR-12, rock, China), and GBW 07102 (rock, China) (Chinese Standard Sample Study Center, Chinese Academy of Measurement Sciences). The relative standard deviation was less than $2.5 \%$, and the detection limit was $10^{-9}$.

\subsection{Data collections}

We collected coal gangue and raw coal production in China from 1992 to 2013 (Li and Sun, 2007; CNCA, 2011; NBSC, 2013a, 2013b, 2014; NDRCC, 2012, 2014), the total emission of sulfur dioxide in China (1992-2013) (MEPC, 1996-2011, 2012-2013), and the numbers of annual average of hazy days in China (1992-2012) (NCCCMA, 2011).

\section{Results and discussion}

\subsection{Average contents of sulfur, arsenic, mercury and fluoride from coal gangue in China}

The content of sulfur, arsenic, mercury, and fluoride in coal gangue samples (including roof, parting, floor, and mixed coal gangue) in this study is listed in Table 1 . Some studies have reported the contents of these elements in Chinese coal gangue based on a certain coal mine (Table 2). However, some factors should be taken into account when element contents in coal gangue are evaluated, such as different coal-forming periods and the different proportions of coal reserves in China. The Permo-Carboniferous coals are the main coals used for power generation in China, accounting for nearly 58\% of Chinese coals (Zeng, 2001). Jurassic coal accounts for about 39\% of Chinese coals (mainly in Northwest China), and the other coals (mainly Triassic, Cretaceous, and Neogene coals) only about 3\% (Chen and Zhang, 1993). Based on the calculation method from Luo et al. (2004a), the weighted average content of these three elements in Chinese coal gangue $\left(C_{0}\right)$ can be expressed as the following equation:

$C_{0}=C_{1} \times 0.39+C_{2} \times 0.58+C_{3} \times 0.03$

where $C_{1}-$ the average content in Jurassic coal gangue; $C_{2}-$ the average content in Permo-Carboniferous coal gangue; $C_{3}-$ the average content in coal gangue in other periods (Zhao, 2007).

Through Eq. (1), the average contents of sulfur, arsenic, mercury, and fluoride in coal gangue in this paper are calculated at $1.01 \mathrm{wt} . \%$ (weight percent), $7.98 \mathrm{mg} / \mathrm{kg}, 0.18 \mathrm{mg} / \mathrm{kg}$, and $365.54 \mathrm{mg} / \mathrm{kg}$, respectively (Table 2). The content of sulfur in coal gangue is quite close to the content of sulfur in coal (1.02 wt.\%) by Luo et al. (2005). What's more, the contents of arsenic and fluoride in coal gangue are higher than those in coal, which are estimated at $4.5 \mathrm{mg} / \mathrm{kg}$ (Luo, 2005), and $3.18 \mathrm{mg} / \mathrm{kg}$ (Kang et al., 2011) for arsenic; and $82 \mathrm{mg} /$ $\mathrm{kg}$ (Luo et al., 2004a), and $130 \mathrm{mg} / \mathrm{kg}$ (Dai and Ren, 2006) for fluoride in Chinese coal, respectively. In addition, the contents of mercury in coal gangue are close to these in Chinese coal which is estimated at $0.15 \mathrm{mg} / \mathrm{kg}$ (Huang and Yang, 2002) and $0.188 \mathrm{mg} / \mathrm{kg}$ (Ren et al., 2006). Furthermore, the contents of sulfur, arsenic, and mercury in coal gangue are obviously higher than their abundance of continental crust (Table 2). Querol et al. (2008) determined that the sulfur, mercury, and arsenic concentrations in fired coal gangue (residual after combustion) are about $0.8 \%, 0.003 \mathrm{mg} / \mathrm{kg}$, and $10 \mathrm{mg} / \mathrm{kg}$, respectively. We analyzed fluoride concentration in fired coal gangue at $148 \mathrm{mg} / \mathrm{kg}$ (Table 2).

\subsection{Estimates of sulfur, arsenic, mercury, and fluoride from spontaneous combustion of coal gangue}

The atmospheric emission of sulfur and potentially toxic elements from coal gangue combustion ( $E$, ton) can be calculated as follows:

$E=A_{\text {coal gangue }} \times\left[C_{\text {coal gangue }}-C_{\text {fired }} \times C_{\text {ash }}\right]$

where $C_{\text {coal gangue }}$ and $C_{\text {fired }}$ are the sulfur and potentially toxic elements concentrations of the coal gangue and the cinder (fired coal gangue) and $C_{\text {ash }}$ is the ash content of coal gangue. $A_{\text {coal gangue }}$ indicate the total amount of coal gangue.

Based on Eq. (2), the emissions of sulfur, arsenic, mercury, and fluoride from spontaneous combustion of coal gangue in China in 2013 are approximately calculated at 1.13 million tons, 246 tons, 45 tons, and 63,298 tons, on complete combustion condition, respectively (Table 3 ). This estimate is based on spontaneous combustion ratio of 1/3 (Querol et al., 2008; Zhao et al., 2008), ash content of $70 \%$ (average values based on our results), coal gangue production 750 million tons in 2013 (NDRCC, 2014), and the mean content of these elements calculated in this paper.

In order to verify the credibility of this estimation, we chose the emission factor of $\mathrm{SO}_{2}(9.84 \mathrm{mg} / \mathrm{g}), \mathrm{H}_{2} \mathrm{~S}(0.61 \mathrm{mg} / \mathrm{g}$ ) (Deng and Cen, 1999), As (1.08 mg/kg), Hg (0.40 mg/kg), and F (271 mg/kg) (Zhao et al., 2008) during spontaneous combustion of coal gangue as reference. Verification results based on emission factor were close to the results of Eq. (2), which showed S (1.31 million t), As (270 t), and $F(67,750 t)$, but the emission of mercury in this work is lower than verification results $(100 \mathrm{t})$.

In this paper, the total amount of sulfur dioxide emission from raw and clean coal in China is estimated approximately at 15.38-18.70 Mt in 2013 based on average sulfur removal rate of China (Table 3). The emission amount of sulfur dioxide from total industrial sources is 20.439 million tons based on official statistics in 2013 (MEPC, 2013), in which coal combustion made up about 75-90\% roughly in this paper. Emissions estimates of sulfur, arsenic, mercury, and fluoride from coal is conducted as well (Table 3). Therefore, emissions of these harmful trace elements such as arsenic and fluoride released into the atmosphere from coal gangue are close or even exceed those from coal combustion (Table 3).

\subsection{Long-term emission trends of sulfur dioxide from coal gangue and total sulfur dioxide emission in China}

Coal mining wastes account for about $10-15 \%$ of the total coal produced in China (Liu and Liu, 2010). There are approximately more than $4.5 \mathrm{Gt}$ of coal gangue cumulated, which occupied more than $15,000 \mathrm{~km}^{2}$ of land in China up to 2010 (Bian et al., 2009; Zhao et al., 2008). The annual production of coal gangue sharply increased after 2000, and the output exceeded 0.75 Gt in 2013 (NDRCC, 2014) (Fig. 2A). Meanwhile, the total raw coal production in China has considerably increased after 2000, and it reached to $3.68 \mathrm{Gt}$ in 2013 (Fig. 2A). Emission trend of sulfur dioxide from spontaneous combustion of coal gangue from 1992 to 2013 is estimated in this paper based on the same emission ratio as in Table 3. This trend shows an accelerated growth after 2002 and reached to $2.25 \mathrm{Mt}$ in 2013 (Fig. 2B).

Chinese official data showed that industrial sulfur dioxide 
Table 1

The contents of sulfur, arsenic, mercury and fluoride in coal gangue in sampled coal mines.

\begin{tabular}{|c|c|c|c|c|c|}
\hline Coalfield & Coal type & Element & Roof & Parting & Floor \\
\hline \multirow[t]{22}{*}{ Huanglong coalfield } & \multirow[t]{4}{*}{ Bindong 1\# coal } & \multirow[t]{2}{*}{ S t.d \% } & $0.27-5.95$ & \multirow[t]{2}{*}{-} & $0.12-2.04$ \\
\hline & & & $1.48(15)$ & & $0.82(14)$ \\
\hline & & $\mathrm{F}$ ad $\mathrm{mg} / \mathrm{kg}$ & $\frac{310-816}{564(15)}$ & - & $\frac{52-700}{468(14)}$ \\
\hline & & As ad $\mathrm{mg} / \mathrm{kg}$ & $\frac{1-13}{7(15)}$ & - & $\frac{0-11}{3(14)}$ \\
\hline & \multirow[t]{6}{*}{ Bindong 5\# coal } & \multirow[t]{2}{*}{ S t.d \% } & $0.02-8.32$ & $0.03-3.34$ & $0.01-3.99$ \\
\hline & & & $1.31(78)$ & $0.79(50)$ & $0.74(78)$ \\
\hline & & \multirow[t]{2}{*}{$\mathrm{F}$ ad $\mathrm{mg} / \mathrm{kg}$} & $82-920$ & $130-800$ & $124-990$ \\
\hline & & & $\overline{615(77)}$ & $\overline{501(49)}$ & $\overline{573(77)}$ \\
\hline & & \multirow[t]{2}{*}{ As ad mg/kg } & $0-35$ & $0-40$ & $0-54$ \\
\hline & & & $\overline{6(77)}$ & $5(50)$ & $4(78)$ \\
\hline & \multirow[t]{6}{*}{ Linyou 2\# coal } & \multirow[t]{2}{*}{ S t.d \% } & $0.02-2.74$ & $0.02-1.38$ & $\underline{0.01-3.03}$ \\
\hline & & & $\overline{0.38(47)}$ & $\overline{0.17(53)}$ & $\overline{0.28(48)}$ \\
\hline & & \multirow[t]{2}{*}{$\mathrm{F}$ ad $\mathrm{mg} / \mathrm{kg}$} & $150-980$ & $\underline{54-1500}$ & $\underline{82-850}$ \\
\hline & & & $\overline{539(46)}$ & $\overline{465(50)}$ & $\overline{489(49)}$ \\
\hline & & As ad $\mathrm{mg} / \mathrm{kg}$ & $0-61$ & $0-12$ & $0-16$ \\
\hline & & & $\overline{5(48)}$ & $\overline{3(51)}$ & $\overline{4(50)}$ \\
\hline & Linyou 3\# coal & S t.d \% & $\underline{0.03-6.30}$ & $\underline{0.01-1.01}$ & $\underline{0.01-0.82}$ \\
\hline & & & $\overline{0.44(36)}$ & $0.15(40)$ & $0.13(39)$ \\
\hline & & $\mathrm{F}$ ad $\mathrm{mg} / \mathrm{kg}$ & $240-1500$ & $36-810$ & $\underline{65-1500}$ \\
\hline & & & $564(37)$ & $369(34)$ & $437(37)$ \\
\hline & & As ad $\mathrm{mg} / \mathrm{kg}$ & $0-16$ & $0-16$ & $\underline{0-31}$ \\
\hline & & & $\overline{6(36)}$ & $4(34)$ & $7(38)$ \\
\hline Weibei coalfield & Hancheng 3\# coal & S t.d \% & $0.21-4.64$ & $0.32-3.79$ & - \\
\hline & & & $0.94(164)$ & $0.82(48)$ & \\
\hline & & $\mathrm{F}$ ad ug/g & $\underline{59-107}$ & $175-616$ & $36(1)$ \\
\hline & & & $78(3)$ & $486(3)$ & \\
\hline & & As ad $\mathrm{mg} / \mathrm{kg}$ & $0-21$ & $14(1)$ & $0-2$ \\
\hline & & & $\overline{12(20)}$ & & $\overline{1(3)}$ \\
\hline & Hancheng $11 \#$ coal & S t.d \% & $0.20-8.00$ & $\underline{0.29-3.25}$ & - \\
\hline & & & $2.76(96)$ & $0.60(64)$ & \\
\hline & & $\mathrm{F}$ ad $\mathrm{mg} / \mathrm{kg}$ & $52-160$ & $69-507$ & $86(1)$ \\
\hline & & & $93(17)$ & $410(4)$ & \\
\hline & & As ad $\mathrm{mg} / \mathrm{kg}$ & $\underline{0-19}$ & $10(1)$ & $\underline{0-3}$ \\
\hline & & & $11(39)$ & & $\overline{2(3)}$ \\
\hline & Chenghe $10 \#$ coal & S t.d \% & $1.50-9.28$ & & \\
\hline & & & $3.65(6)$ & & \\
\hline & & $\mathrm{F}$ ad $\mathrm{mg} / \mathrm{kg}$ & $98.75-1526.41$ & & \\
\hline & & & $851.25(6)$ & & \\
\hline & & As ad $\mathrm{mg} / \mathrm{kg}$ & $12.66-78.72$ & & \\
\hline & & & $34.91(6)$ & & \\
\hline & & $\mathrm{Hg}$ ad mg/kg & $0.14-0.34$ & & \\
\hline & & & $0.23(6)$ & & \\
\hline & Tongchuan $11 \#$ coal & S t.d \% & $0.45(1)$ & & \\
\hline & & $\mathrm{F}$ ad $\mathrm{mg} / \mathrm{kg}$ & $346.50(1)$ & & \\
\hline & & As ad mg/kg & $0.715(1)$ & & \\
\hline & & $\mathrm{Hg}$ ad $\mathrm{mg} / \mathrm{kg}$ & $0.21(1)$ & & \\
\hline Shenfu coalfield & Shenfu 5\# coal & S t.d \% & $0.7(1)$ & & \\
\hline & & $\mathrm{F}$ ad $\mathrm{mg} / \mathrm{kg}$ & $28.94(1)$ & & \\
\hline & & As ad mg/kg & $2.78(1)$ & & \\
\hline & & $\mathrm{Hg}$ ad $\mathrm{mg} / \mathrm{kg}$ & $0.08(1)$ & & \\
\hline Xishan coalfield & Xishan 8\# coal & S t.d \% & $1.28(1)$ & & \\
\hline & & $\mathrm{F}$ ad $\mathrm{mg} / \mathrm{kg}$ & $\underline{54.4-223.09}$ & & \\
\hline & & & $156.67(3)$ & & \\
\hline & & As ad $\mathrm{mg} / \mathrm{kg}$ & $0.60-2.92$ & & \\
\hline & & & $\overline{1.85(3)}$ & & \\
\hline & & $\mathrm{Hg}$ ad mg/kg & $0.14-0.35$ & & \\
\hline & & & $0.26(3)$ & & \\
\hline Pingyinan coalfield & Pingyin 7\# coal & S t.d \% & $1.44(1)$ & & \\
\hline & & $\mathrm{F}$ ad $\mathrm{mg} / \mathrm{kg}$ & $167.76(1)$ & & \\
\hline & & As ad mg/kg & $1.4(1)$ & & \\
\hline & & $\mathrm{Hg}$ ad mg/kg & $0.36(1)$ & & \\
\hline
\end{tabular}

Notes:

i) $\mathrm{F}$ ad, As ad, and $\mathrm{Hg}$ ad are fluoride, arsenic, and mercury contents in coal gangue with air dry basis.

ii) $\mathrm{S}$ t.d is total sulfur content in coal gangue with dry basis.

iii) The numbers above/below the line are concentration ranges/arithmetic average values, and numbers in parentheses mean sample numbers used for this study.

emissions peaked in 2006 (25.88 Mt), and then it showed a downward trend (average annual decrease rate at $3.88 \%$ ), especially after 2008 Beijing Olympic Games (MEPC, 1996-2011, 2012-2013) (Fig. 2B). Some other studies show a similar trend of sulfur dioxide emissions in China that reduction of emissions occurred after the peak value in 2006 (e.g. Zhang et al., 2012; Klimont et al., 2013). This trend may be attributed to increasing of FGD installations in Chinese power plants under stricter emission limits (Xu, 2011). 
Table 2

The contents of sulfur, arsenic, mercury and fluoride in Chinese coal gangue and background values.

\begin{tabular}{|c|c|c|c|c|c|c|}
\hline Locations & $\mathrm{S}(\%)$ & As (mg/kg) & $\mathrm{Hg}(\mathrm{mg} / \mathrm{kg})$ & $\mathrm{F}(\mathrm{mg} / \mathrm{kg})$ & Number of samples & Reference \\
\hline Yangquan, Shanxi & 0.8 & 10 & 0.4 & - & - & Querol et al., 2008 \\
\hline Yangquan, Shanxi & $<0.5$ & 3.6 & 0.3 & 223.0 & 90 & Zhao et al., 2008 \\
\hline Yangquan, Shanxi & 1.51 & - & 0.76 & - & - & Zhang, 2013 \\
\hline Jingxing, Hebei & 2.98 & - & 0.719 & - & - & Zhang, 2013 \\
\hline Fengfeng, Hebei & 1.36 & - & 0.247 & - & - & Zhang, 2013 \\
\hline Yanzhou, Shandong & - & 5.34 & 1.86 & - & - & Feng and Liu, 2002 \\
\hline Huainan, Anhui & - & 3.92 & 0.07 & 250 & 44 & Cui et al., 2004 \\
\hline Huainan, Anhui & 0.07 & 2.47 & 0.08 & 242.57 & 31 & Cai et al., 2008 \\
\hline Huainan, Anhui & 1.31 & 3.48 & - & - & 11 & Zhou et al., 2012 \\
\hline Huainan, Anhui & $1.32-2.03$ & 6.85 & - & - & 10 & Zhou et al., 2014 \\
\hline Xuzhou, Jiangsu & 0.64 & - & - & - & - & Li et al., 2006 \\
\hline Beijing & 0.12 & - & - & - & - & Li et al., 2006 \\
\hline Puhe, Liaoning & 0.11 & 3.50 & 0.1 & 290.0 & 2 & Zhao, 2007 \\
\hline Santa Catarina, Brazil ${ }^{a}$ & - & $6.0-43.7$ & 0.19 & - & 39 & Silva et al., 2011 \\
\hline World average values in coal & 2 & 8.3 & 0.1 & 88 & - & Valković, 1983; Ketris and Yudovich, 2009 \\
\hline Crust abundance & 0.07 & 1.7 & 0.04 & 525 & - & Wedepohl, 1995 \\
\hline Weighted value of coal gangue & 1.01 & 7.98 & 0.18 & 365.54 & - & This work \\
\hline
\end{tabular}

a The samples are coal cleaning residues.

Table 3

Emissions estimates of sulfur, arsenic, mercury and fluoride from combustion of coal gangue and coal in China.

\begin{tabular}{|c|c|c|c|}
\hline & \multirow[t]{2}{*}{ Coal gangue } & \multicolumn{2}{|l|}{ Coal } \\
\hline & & Raw coal & Clean coal \\
\hline Production in 2013 (million tons) & 750 & $1472^{\mathrm{a}}$ & $2208^{\mathrm{a}}$ \\
\hline Sulfur content (wt \%) & 1.01 & $1.34^{\mathrm{b}}$ & $0.5-0.8^{\mathrm{b}}$ \\
\hline Sulfur emission (million tons $\mathrm{a}^{-1}$ ) & 1.13 & $4.93^{c}$ & $2.76-4.42^{c}$ \\
\hline Sulfur dioxide emission (million tons $\mathrm{a}^{-1}$ ) & 2.26 & 9.86 & $5.52-8.84$ \\
\hline \multirow[t]{2}{*}{ Arsenic emission (ton $\mathrm{a}^{-1}$ ) } & 246 & 195 (Luo et al., 2004b) & \\
\hline & & 236 (Chen et al., 2013) & \\
\hline \multirow[t]{3}{*}{ Mercury emission (ton $\mathrm{a}^{-1}$ ) } & 45 & 202 (Streets et al., 2005) & \\
\hline & & 257 (Wu et al., 2006) & \\
\hline & & 172 (Chen et al., 2013) & \\
\hline \multirow[t]{2}{*}{ Fluoride emission (ton $\mathrm{a}^{-1}$ ) } & 63,298 & 66,398 (Luo et al., 2002) & \\
\hline & & 162,161 (Chen et al., 2013) & \\
\hline
\end{tabular}

a The raw and clean coal production was based on the total production of coal at 3680 million tons and the raw coal washing rate at nearly $60 \%$ in 2013 (http:// www.coalchina.org.cn/detail/14/01/16/00000012/content.html).

b The average content of sulfur in coal was from Ren et al. (2006).

${ }^{c}$ Emission of sulfur after desulphurization was calculated according to the average removal rate of $\mathrm{SO}_{2}$ (75\%) of thermal power plants in China (MEPC, 2012).
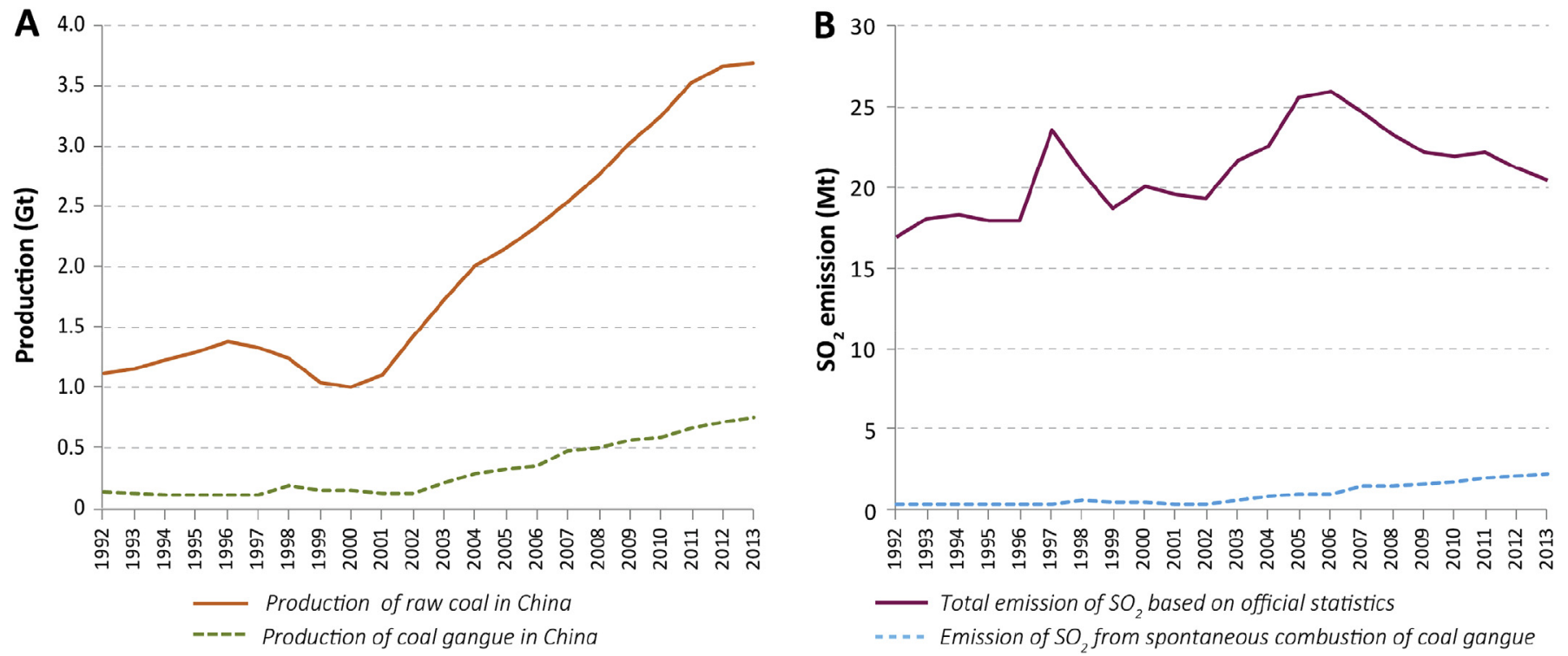

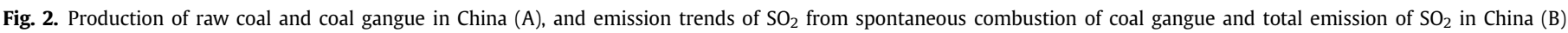
(1992-2013) 
However, the statistics data about continuously worsening atmospheric environment, e.g. increase of number of hazy days, show an increasing trend in recent years (NCCCMA, 2011; Wang et al., 2014). Based on the estimate above, the amount of sulfur dioxide emission from coal gangue is becoming an important factor which shows a rapidly growing trend after 2002 with the ratio more than $10 \%$ of the total amount of sulfur dioxide emission.

\subsection{Implications and limitations}

According to the data from environmental monitoring, continuous heavy haze pollution increased dramatically in China (Cheng et al., 2013; Wang et al., 2014; Gao et al., 2015). The average numbers of haze days in China shows a rising trend from 1992 to 2013 (NCCCMA, 2011; MEPC, 1996-2011; MEPC, 2012-2013), and it indicates the trend of accelerating growth after 2002. China's coal gangue production growth from 1992 to 2013 shows almost the same year after which the production of coal gangue exhibits an obvious growth (Fig. 2). Furthermore, emission of sulfur dioxide from spontaneous combustion of coal gangue exhibits an accelerated growth after 2002 as well.

Even most of coal gangue has much higher contents of sulfur and other hazardous trace elements than coal, some of coal gangue used as small power station, domestic heating, and as a component for construction materials (e.g. cement and brick) (Xiao et al., 2015). All these processes as the spontaneous combustion of coal gangue, are without any desulfurization equipment, and the emissions of hazardous substances have not yet been included in the statistics. What's more, all of the emissions of hazardous substances from coal gangue used or spontaneous combustion have not yet been included in the statistics. The finding in this paper may imply that coal gangue spontaneous combustion is the potential sources of sulfur, arsenic, mercury, and fluorine emissions to air pollution in China. Unsustainable coal mining, processing, and utilization produce large amounts of potential pollution sources, and this situation may last for years (Yu and Wei, 2012). Therefore, the measures of emission control should be integrated with management of mining waste, such as coal gangue piles in China's coal mining areas (Fan et al., 2014).

It should be noted that although most of coal gangue has much higher contents of sulfur and other hazardous trace elements than coal, their contents variation shows wide ranges among different coal-forming basins, hence, it is still difficult to accurately estimate their concentrations in coal gangue at the national level. Consequently, for further research, more precise estimate of atmospheric emission amount of these elements is still needed by extensive studies with further collection of samples, and more in-depth investigation is required to improve and validate the results of this paper as well.

\section{Conclusions}

The aim of this work is to provide a rough estimate of the total annual amount of sulfur, arsenic, mercury, and fluoride emission from spontaneous combustion of coal gangue. For this purpose, we determine and calculate the average sulfur, arsenic, mercury and fluorine contents of Chinese coal gangue, based on weighted coal reserves in main coal-forming period. Weighted mean contents of sulfur, arsenic, mercury, and fluoride in coal gangue are $1.01 \%$, $7.98 \mathrm{mg} / \mathrm{kg}, 0.18 \mathrm{mg} / \mathrm{kg}$, and $365.54 \mathrm{mg} / \mathrm{kg}$, respectively, which are close to or higher than those in Chinese coal. Furthermore, we provide a rough estimate of the total annual amount of these elements emissions from spontaneous combustion of coal gangue. The results show approximately S (1.13 Mt), As (246 tons), Hg (45 tons), and $F(63,298$ tons $)$ in 2013 , respectively.
The results indicate two main points. Firstly, the emissions of sulfur, arsenic, and fluoride released into the atmosphere from coal gangue account more than 10\% (sulfur) or even exceed (arsenic and fluoride) those from coal combustion. Moreover, emission of mercury is equal to nearly a quarter of total emission from coal combustion. So, sulfur, arsenic, mercury, and fluorine emissions due to spontaneous combustion of coal gangue is an important part of Chinese emission inventories. Secondly, emission of sulfur dioxide from spontaneous combustion of coal gangue from 1992 to 2013 show almost the same year (around 2002) after which the production of coal gangue exhibits an obviously growth. The results in this paper indicate that practical management of mining waste, such as coal gangue piles in China's coal mining areas should be integrated into national emission reduction policies. More precise and in-depth work are still needed to evaluate the environmental impact of coal gangue spontaneous combustion in the future.

\section{Competing financial interests}

The authors declare no competing interests.

\section{Acknowledgments}

Financial supports for this research were provided by the National Basic Research Program of China (973 Program) (Grant no. 2014CB238906) and the National Natural Sciences Foundation of China (Grant no. 41472322 and 41172310). We would like to thank Dr. C. Zhao, Dr. L. P. Dong and Dr. X. J. Han for providing language help.

\section{References}

Administration of Quality Supervision, Inspection and Quarantine (AQSIQ), Standardization Administration of the P. R. China (SAC), 2007. Determination of Total Sulfur in Coal (GB/T214-2007).

Bian, Z., Dong, J., Lei, S., Leng, H., Mu, S., Wang, H., 2009. The impact of disposal and treatment of coal mining wastes on environment and farmland. Environ. Geol. $58,625-634$

Cai, F., Liu, Z.G., Lin, B.Q., Li, W., Lv, Z., 2008. Study on trace elements in gangue in Huainan mining area. J. China Coal Soc. 33, 892-897 (in Chinese with English abstract).

Chen, J., Liu, G., Kang, Y., Wu, B., Sun, R., Zhou, C., Wu, D., 2013. Atmospheric emissions of $\mathrm{F}, \mathrm{As}, \mathrm{Se}, \mathrm{Hg}$, and $\mathrm{Sb}$ from coal-fired power and heat generation in China. Chemosphere 90, 1925-1932.

Chen, W.M., Zhang, Z.S., 1993. Coal Chemistry. Coal Industry Press, Beijing (in Chinese).

Cheng, Z., Wang, S., Jiang, J., Fu, Q., Chen, C., Xu, B., Yu, J., Fu, X., Hao, J., 2013. Longterm trend of haze pollution and impact of particulate matter in the Yangtze River Delta, China. Environ. Pollut. 182, 101-110.

China National Coal Association (CNCA), 2011. Compile of Coal Industry Statistics of China, 1949-2009. China Coal Industry Publishing House, Beijing (in Chinese).

Cui, L.P., Bai, J.F., Huang, W.H., Shi, Y.H., Yan, S.L., Tang, X.Y., Hu, Y.B., Xiong, Y., 2004 Environmental trace elements in coal mining waste in Huainan coal field. Geochimica 33, 535-540 (in Chinese with English abstract).

Dai, S., Ren, D., 2006. Fluorine concentration of coals in China-an estimation considering coal reserves. Fuel 85, 929-935.

Deng, D.H., Cen, W.L., 1999. Environmental effect of coal gangue stack area. China Min. Mag. 8 (6), 87-91 (in Chinese with English abstract).

Fan, G., Zhang, D., Wang, X., 2014. Reduction and utilization of coal mine waste rock in China: a case study in Tiefa coalfield. Resources,. Conserv. Recycl. 83, 24-33.

Feng, Q.Y., Liu, G.J., 2002. Harmful microelements contained in gangue from Yanzhou coal mine and their influences to the soil. China Min. Mag. 11, 67-69 (in Chinese with English abstract).

Fu, T., Wu, Y., Ou, L., Yang, G., Liang, T., 2012. Effects of thin covers on the release of coal gangue contaminants. Energy Proced. 16 (Part A), 327-333.

Gao, J., Tian, H., Cheng, K., Lu, L., Zheng, M., Wang, S., Hao, J., Wang, K., Hua, S. Zhu, C., Wang, Y., 2015. The variation of chemical characteristics of $\mathrm{PM}_{2.5}$ and $\mathrm{PM}_{10}$ and formation causes during two haze pollution events in urban Beijing, China. Atmos. Environ. 107, 1-8.

Gu, Q., 1997. Composition and utilization of gangue in China. China Min. Mag. 6, 14-16 (in Chinese).

He, K., Huo, H., Zhang, Q., 2002. Urban air pollution in China: current status, characteristics, and progress. Annu. Rev. Energy Environ. 27, 397-431.

Huang, W.H., Yang, Y.C., 2002. Mercury in coal of China. Coal Geol. China 14 Supp, 37-40 (in Chinese with English abstract). 
Kang, Y., Liu, G., Chou, C.-L., Wong, M.H., Zheng, L., Ding, R., 2011. Arsenic in Chinese coals: distribution, modes of occurrence, and environmental effects. Sci. Total Environ. 412-413, 1-13.

Ketris, M.P., Yudovich, Y.E., 2009. Estimations of clarkes for carbonaceous biolithes: world averages for trace element contents in black shales and coals. Int. J. Coal Geol. 78, 135-148.

Klimont, Z., Smith, S.J., Cofala, J., 2013. The last decade of global anthropogenic sulfur dioxide: 2000-2011 emissions. Environ. Res. Lett. 8, 014003.

Leung, P.Y., Wan, H.T., Billah, M.B., Cao, J.J., Ho, K.F., Wong, C.K.C., 2014. Chemical and biological characterization of air particulate matter 2.5, collected from five cities in China. Environ. Pollut. 194, 188-195.

Li, D., Song, X., Gong, C., Pan, Z., 2006. Research on cementitious behavior and mechanism of pozzolanic cement with coal gangue. Cem. Concr. Res. 36 1752-1759.

Li, Q., Sun, G.N., 2007. Synopsis of regenerative utilization ways of coal gangue resource in China. Fly Ash Compr. Util. 3, 51-53 (in Chinese with English abstract).

Liu, H., Liu, Z., 2010. Recycling utilization patterns of coal mining waste in China. Resour. Conserv. Recycl. 54, 1331-1340.

Liu, Y. Luo, K. Li, L., Shahid, M.Z., 2013. Fluoride and sulfur dioxide indoor pollution situation and control in coal-burning endemic area in Zhaotong, Yunnan, China. Atmos. Environ. 77, 725-737.

Luo, K., 2005. Arsenic content and distribution pattern in Chinese coals. Toxicol. Environ. Chem. 87, 427-438.

Luo, K., Ren, D., Xu, L., Dai, S., Cao, D., Feng, F., Tan, J., 2004a. Fluorine content and distribution pattern in Chinese coals. Int. J. Coal Geol. 57, 143-149.

Luo, K., Xu, L., Li, R., Xiang, L., 2002. Fluorine emission from combustion of steam coal of north China plate and northwest China. Chin. Sci. Bull. 47, 1346-1350.

Luo, K., Zhang, X., Chen, C., Lu, Y., 2004b. Estimate of arsenic emission amount from the coal power stations in China. Chin. Sci. Bull. 49, 2183-2189.

Luo, Y., Li, W., Jiang, Y., Bai, X., 2005. Distribution of sulfur in coals of china. Coal Convers. 28, 14-18 (in Chinese with English abstract).

Ma, J., Chen, Y., Wang, W., Yan, P., Liu, H., Yang, S., Hu, Z., Lelieveld, J., 2010. Strong air pollution causes widespread haze-clouds over China. J. Geophys. Res. Atmos. 115 http://dx.doi.org/10.1029/2009JD013065.

Mao, J.H., Xu, H.L., 1999. China's coal resource distribution and perspective prediction. Coal Geol. Explor. 27, 1-4 (in Chinese with English abstract).

Ministry of Environmental Protection of China (MEPC), 1996-2011. Report on the State of the Environment in China. http://english.mep.gov.cn/standards reports/soe.

Ministry of Environmental Protection of China (MEPC), 2012-2013. Report on the State of the Environment in China. http://jcs.mep.gov.cn/hjzl/zkgb/.

National Bureau of Statistics of China (NBSC), 2014. China Energy Yearbook, 2013. China Statistics Press, Beijing.

National Bureau of Statistics of China (NBSC), 2013a. China Energy Yearbook of 2012. China Statistics Press, Beijing, China.

National Bureau of Statistics of China (NBSC), 2013b. Statistical Communiqué of the People's Republic of China on the 2012 National Economic and Social Development. China Statistics Press, Beijing, China.

National Climate Center of China Meteorological Administration (NCCCMA), 2011 China Climate Change Bulletin (in Chinese).

National Development and Reform Commission of China (NDRCC), 2012. Annual Report on Resources Comprehensive Utilization in China (in Chinese), http:/ www.gov.cn/gzdt/2013-04/08/content_2372577.htm.

National Development and Reform Commission of China (NDRCC), 2014. Annual Report on Resources Comprehensive Utilization in China (in Chinese), http:// www.sdpc.gov.cn/xwzx/xwfb/201410/t20141009_628793.html.

Ni, R. Luo, K., 2015. Determination of total selenium and arsenic in coal by wet digestion hydride generation atomic fluorescence spectrometry (HG-AFS). Spectrosc. Spectr. Anal. 35 (5), 1404-1408 (in Chinese with English abstract).

Querol, X., Izquierdo, M., Monfort, E., Alvarez, E., Font, O., Moreno, T., Alastuey, A.
Zhuang, X., Lu, W., Wang, Y., 2008. Environmental characterization of burnt coal gangue banks at Yangquan, Shanxi Province, China. Int. J. Coal Geol. 75, 93-104.

Ren, D.Y., Zhao, F.H., Dai, S.F., Luo, K.L., 2006. Geochemistry of Trace Elements in Coals. The Science Press, Beijing, pp. 268-279 (in Chinese).

Silva, L.O., Wollenschlager, M., Oliveira, M.S., 2011. A preliminary study of coal mining drainage and environmental health in the Santa Catarina region, Brazil. Environ. Geochem. Health 33, 55-65.

Streets, D.G., Hao, J., Wu, Y., Jiang, J., Chan, M., Tian, H., Feng, X., 2005. Anthropogenic mercury emissions in China. Atmos. Environ. 39, 7789-7806.

Tian, H.Z., Wang, Y., Xue, Z.G., Cheng, K., Qu, Y.P., Chai, F.H., Hao, J.M., 2010. Trend and characteristics of atmospheric emissions of $\mathrm{Hg}$, As, and Se from coal combustion in China, 1980-2007. Atmos. Chem. Phys. 10, 11905-11919.

Tie, X., Brasseur, G.P., Zhao, C., Granier, C., Massie, S., Qin, Y., Wang, P., Wang, G., Yang, P., Richter, A., 2006. Chemical characterization of air pollution in Eastern China and the Eastern United States. Atmos. Environ. 40, 2607-2625.

Valković, V., 1983. Trace Elements in Coal, 1. CRC Press, Inc, Florida.

Wang, O., Shen, W., Ma, Z., 2000. Estimation of mercury emission from coal combustion in China. Environ. Sci. Technol. 34, 2711-2713.

Wang, Y., Ying, Q., Hu, J., Zhang, H., 2014. Spatial and temporal variations of six criteria air pollutants in 31 provincial capital cities in China during 2013-2014. Environ. Int. 73, 413-422.

Wedepohl, K.H., 1995. The composition of the continental crust. Geochim. Cosmochim. Acta 59, 1217-1232.

Wu, Y., Wang, S., Streets, D.G., Hao, J., Chan, M., Jiang, J., 2006. Trends in anthropogenic mercury emissions in China from 1995 to 2003. Environ. Sci. Technol. 40, 5312-5318.

Xiao, J., Li, F., Zhong, Q., Bao, H., Wang, B., Huang, J., Zhang, Y., 2015. Separation of aluminum and silica from coal gangue by elevated temperature acid leaching for the preparation of alumina and SiC. Hydrometallurgy 155, 118-124.

$\mathrm{Xu}, \mathrm{Y} ., 2011$. Improvements in the operation of $\mathrm{SO}_{2}$ scrubbers in China's coal power plants. Environ. Sci. Technol. 45, 380-385.

Yang, J.H., Chen, W.M., Duan, Y.L., 1998. Handbook of Coal Testing. Coal Industry Press, Beijing (in Chinese).

You, C., Xu, X., 2010. Coal combustion and its pollution control in China. Energy 35, $4467-4472$.

Yu, S., Wei, Y., 2012. Prediction of China's coal production-environmental pollution based on a hybrid genetic algorithm-system dynamics model. Energy Policy 42 , 521-529.

Zeng, Y., 2001. Special coal types in Western China and their exploitation and utilization. J. China Coal Soc. 26 (4), 337-340 (in Chinese with English abstract).

Zhang, B.W., 2013. Research on the Characteristics of Mercury Emissions from Coal Gangue. Thesis for the Master Degree. North China Electric Power University (in Chinese with English abstract).

Zhang, Q., He, K., Huo, H., 2012. Policy: cleaning China's air. Nature 484, 161-162.

Zhang, X.M., Luo, K.L., Sun, X.Z., Tan, J.A., Lu, Y.L., 2006. Mercury in the topsoil and dust of Beijing City. Sci. Total Environ. 368, 713-722.

Zhang, Y., Zhao, B., 2007. Simulation and health risk assessment of residential particle pollution by coal combustion in China. Build. Environ. 42, 614-622.

Zhao, H.Z., 2007. Study on Geochemical Characteristics of Coal Gangue and its Utilization in the Southern Part of Liaoning and Jilin Province. Thesis for the Master Degree. Jilin University (in Chinese with English abstract).

Zhao, Y., Zhang, J., Chou, C.L., Li, Y., Wang, Z., Ge, Y., Zheng, C., 2008. Trace element emissions from spontaneous combustion of gob piles in coal mines, Shanxi, China. Int. J. Coal Geol. 73, 52-62.

Zhou, C., Liu, G., Wu, S., Lam, P.K.S., 2014. The environmental characteristics of usage of coal gangue in bricking-making: a case study at Huainan, China. Chemosphere 95, 274-280.

Zhou, C., Liu, G., Yan, Z., Fang, T., Wang, R., 2012. Transformation behavior of mineral composition and trace elements during coal gangue combustion. Fuel 97, $644-650$ 